\title{
Memoirs of a socialist childhood in China: socialism, nationalism and getting ahead
}

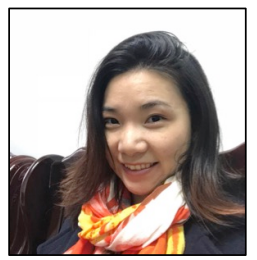

Lei Chen

Shaanxi Normal University, China

\begin{abstract}
In this memoir, I accounted several episodes of my childhood of a middle class family in early 1990s in a Chinese urban city. Two major discourses permeated my account: the nationalism and socialism discourse and the upward social mobility discourse. While my family and I cherish the comfort and joy of everyday life enjoyed in the era of "socialism with Chinese characteristics", the suffering past is like a ghost, peeking out behind the curtain.
\end{abstract}

Lei Chen: Upon finishing my PhD at School of Education, University of Delaware, USA in 2017, I proudly joined Shannxi Normal University, Xi'an, Shaanxi, P.R. China. My current work focuses on teacher training in both B.A. and M.A. programs. I teach a number of classes in second language teaching, second language acquisition, applied linguistics and social linguistics. I am interested in understanding teaching and teachers from sociocultural perspective and was drawn to the studies of dialogic pedagogy in second language classes.

$\cos 0380$

I was born in 1987, in a middle-class family ${ }^{1}$ in Wuhan, a populated city along Yantze river in China, about 9 years after the "reform and open" policy ${ }^{2}$ (改革开放). My childhood memory was marked by socialist songs and stories of child heroes in battles against Japanese invaders during the WWII. And I also remember vividly the desire for a pink dress branded by Disney ${ }^{3}$, and endless late night study hours for school exams. Therefore, I think my childhood memory can be characterized by a phrase often used in Chinese media, socialism with Chinese characteristics ${ }^{4}$ (中国特色的社会主义).

I am quite aware that the stories I told was from the perspective of a middle class family in a populated city as poverty still exists in rural areas in China. There is also a saying that since China develops so fast, every five years, China witnessed a new generation. Thus, I belong to the post- 85 generation. ${ }^{5}$ My

\footnotetext{
${ }^{1}$ In Chinese political discourse, the concept of middle class is termed as xiao kang, (小康), moderately prosperous or basically "welloff". I classified myself as "middle class" since my father has a college degree and a professional job. Please refer to https://en.wikipedia.org/wiki/Moderately_prosperous_society for more information.

2 The Chinese economic reform (literally, "reform and opening-up"), led by Deng Xiaoping, refers to the program of economic reforms in China that was started in December 1978. The economic reform introduced market principles by decollectivization of agriculture, privatization and contracting out of much state-owned industry and the lifting of price controls as well as other policies. The reform successfully led to unprecedented growth and elimination of poverty in urban China as well as drastically increased living standards in rural China.

${ }^{3}$ With the "reform and open" policy, China started to import and translate Disney movies since 1981.

${ }^{4}$ Officially, China is a socialist country rather than "post-socialist". The political and economic reform gave the socialism some "Chinese characteristics".

${ }^{5}$ Born after 1985 and before 1990.
} 
generation is different from post-80 generation or post- 90 generation. Post-80 generations might have some memories of living in courtyard homes and shared bathrooms with extended families. Post- 90 generations would remember themselves living in apartment buildings with elevators. Post-85 remember the transition from the former to the latter.

Two major discourses (in my analysis) permeated in my memoir of childhood. First, the formal and official socialist and nationalist discourse - this discourse emphasizes loyalty to the nation, the Party, and the revolutionary past, as well as high appreciation of the economic development that "New China"6 has achieved. Second, the informal discourse by my parents, which emphasizes pursuing and cherishing the comfort and joy of everyday life. The "reform and open" policy offers unprecedented opportunity for upward social mobility in urban China. Also influenced by Confucianism that education will transfer to economic benefit, the lessons that I received from the informal discourse of social mobility is simple: "getting ahead" through education to ensure a comfortable life for my future.

In some episodes of my memories, the two discourses merge: sometimes, you can "get ahead" in education by demonstrating your loyalty to the Communist Party. For instance, an exemplary student who won revolutionary songs competition would mean access to better educational opportunities. However, in other episodes, the two discourses conflict. To enter the No.1 Middle School in my city, I had to focus on my academic study to pass an intense standardized test. Thus, I was not allowed to participate in the school organized after-class-activities that showcase my loyalty to the Party and the nation because such activities distract me from my study.

I regard the second discourse of comfort and joy of everyday life vastly different from the informal discourse in other socialist childhood memoirs discussed in this special issue. For instance, Matusov (in this special issue) discusses critical reflections of the socialist policy in the economically and politically stagnant USSR of the mid 1960s - the beginning of 1980s and Marjanovic-Shane (in this special issue) discusses enjoyable freedom for children's creation in the Socialist Federal Yugoslavia. In my case, the informal discourse in China is Chinese teacher or parents' responses to the vast social and economic changes in 1990s-getting ahead against all the odds. Witnessing the possibility of social mobility in the 1990s and influenced by the Confucius teaching which highly values education and educational degrees, teachers and parents gave me one instruction: study study and study.

The search for the literature examining Chinese childhood in 1980s from sociocultural perspectives did not yield many studies or memoirs of post-socialist Chinese childhood. In my analysis, there might be two reasons. First, China is still, in nowadays, a socialist country and therefore, there is not enough distance to view the socialist regime analytically and critically. Second, there are many "non-socialist" elements in childhood or daily life in China since 1980s. For instance, after "the reform and open" policy, there is a flux of Western books, movies, children's book. Many Chinese children in city grew up with Barbie and Disney movies like their Western counterparts. Although there were definitely some socialist elements in 1980s, for instance, the election of young pioneers that will be discussed in this memoir, the capitalist influence was rather salient.

My memoirs of socialist childhood feature three themes. First, the official socialist and nationalist ideology that is handed down through school curriculum, classroom decorations, morning meetings, the red-collar child's community group and other institutional environments. Second, the informal discourse that

\footnotetext{
6 "New China" refers to the rule of the Communist Party of China since 1945.
} 
focus on opportunities and competition. Third, the relationship between the two discourses: conflicts and intersections.

I tell these themes through diverse sources: 1) the official socialist and nationalist ideology in my school system, 2) how as a child, I navigated the formal and informal discourse, 3) my parents' memories about their childhood which explains some of their parenting choices.

\section{The official socialist and nationalist ideology}

I entered the elementary school in 1994 . While I had previously considered my elementary school as "normal" and "there's nothing to say," when I first started writing for this project, I surprisingly found my memory similar to Matusov (in this special issue) discussion of Soviet schools thirty years before my childhood. I suppose such similarity is what marked its socialist and nationalist nature.

The classroom settings of my school was similar to Matusov's discussions (see it in this special issue). In my elementary school, we sat in rows all facing the blackboard in the front. On the top of the blackboard, there was a picture of the national flag or a photo of Chairman Mao. On the left and right side of the flag, were patriotic mottos like this, for example: "Work diligently, study tediously, love your country, and live honestly." The school desks were for two pupils to share and teachers deliberately had boys sit with girls to prevent the students from talking to each other so that the students could focus on learning ${ }^{7}$.

The socialist and nationalist regime was also passed down through the official school academic curricula. In language art classes, we read stories of the revolutionary time: the Red Army endured great difficulties to fight the enemies. The Prime Minister Zhou worked until midnight to manage the country. The wife of Prime Minister Zhou sewed and mended his socks to save money for the revolution. We had an ideological and ethical education class once a week since first grade. In those lessons, we read about little children were tortured in capitalist factories and the sacrifices of revolutionary heroes. Those lessons taught us: Capitalism is evil. Poor people in the capitalist society could hardly survive, and we need to feel fortunate that we live in a socialist country. While it is easy to get hold of Disney stories in bookstores, those stories were not included in the curriculum.

The school was very much organized in an army regime. In our class of 50 pupils, we had one "head of class", and four "head of small groups". Since the first day of first grade, I was appointed "headof-the-small-group", as the teacher quickly discovered that I was clever with the academic subjects. This meant I would be in charge of a small group of six students. The "head of class" was in charge of all the "head-of-the-small-groups". Whenever there was noise in class, the teacher would ask: "All head-of-thegroups, please report who (which student) is (illegally) speaking!"

The students wore insignia to show that they belonged to different "rank." "Head of the small groups" wore one bar on the badge, while "the head of the class" wore two bars on the badge. For each grade of around 200 students, there was a student of three bars on the badge. Besides the badge, out of 50 students in the class, 20 students were "young pioneers" and wore red scarf to showcase their "advance" in moral and in behavior/performance.

\footnotetext{
${ }^{7}$ In my analysis, the official discourse is genderless and ignores the students' reality of socializing with different gender. I often hear teachers say: "How the hell do you, girls, have so much to say with boys?"
} 


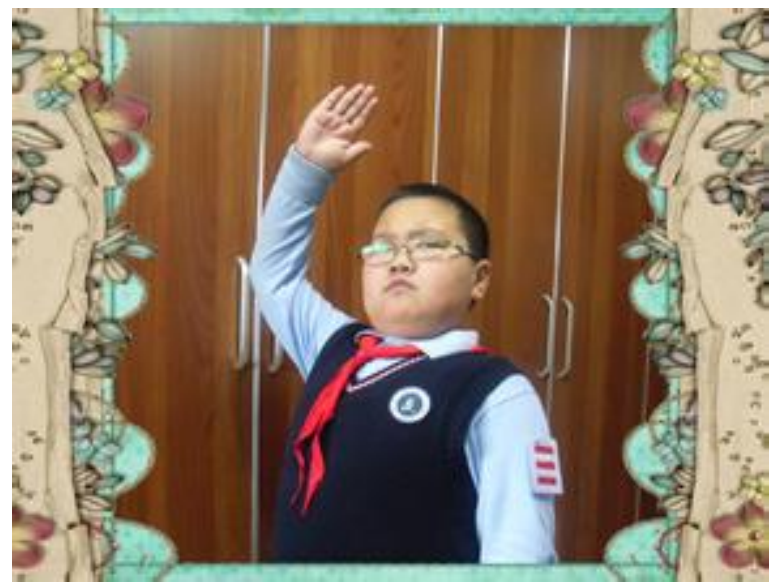

Picture 1. A boy wearing red scarf and three bars. Picture is from an online blog.

\section{Navigating the official and unofficial discourses}

Interestingly, in our time (socialist society), the official socialist and nationalist discourse was much contested at the school and at home. While a rank could transfer to privileges and opportunities in education, sometimes, parents regard school rank as a burden from preparing for middle school entrance examination.

I, on the other hand, remembered that my mom asked me to return my two-bar badge to the teacher. My mother felt the responsibilities that came with "the head of the class", including grading other students' homework and making sure that my classmates cleaned the classrooms on time "wasted my time". She thought that my time should be "better" spent doing practice tests towards the middle school entrance examination. In my mind, returning the badge to the teacher felt like a defiance to the honor that the school and the Party had given me. In my mom's perspective, this honor would matter little twenty years later, but the opportunity to go to a highly qualified middle school would. Twenty years later, when I did my fieldwork in an elementary school in the U.S. and realized that there was nothing like "two bars" in the U.S., I thought: so the children in the U.S. did not need to choose whether to follow the school or the parents. What a relieved childhood!

Another big step to show your loyalty to the Party is through joining "young pioneers." In Chinese elementary schools, a few months after the students entered the institution during the first grade, there came the time to elect a small group of first graders to join the "young pioneers". "Young pioneers" wore a red scarf which is a token for the red national flag, symbolizing the blood of revolutionaries fought for the better future. Joining "young pioneers" manifests that you are "an exemplary student". Unlike American concept of Girls' Scouts' selling cookies for camping, this is more like the Chinese adults' joining the Chinese Communist Party. It is an honor that is associated with various aspects of life. The red scarfs were awarded in a ceremony, after which we were required to wear the red scarf every day to demonstrate that we remembered the national flag and all the people who sacrificed their lives in the revolution to give us the peaceful life.

One day during the first grade, the rumor went out that we, as a student group, were going to elect the young pioneers. In our class of 50 students, only about 10 students would be selected the "young pioneers" for their excellency in academic performance and high moral and ideological standing. Being a leader of a small group gave me a head start in the election. Some group leaders would talk to their 
members: "If you vote for me during the election, I would not write your name when you talk in class." In this kind of environment, some fellow group members felt a strong sense of belonging for their groups during the election and would campaign for their group leaders. "I will let you copy my homework, and you

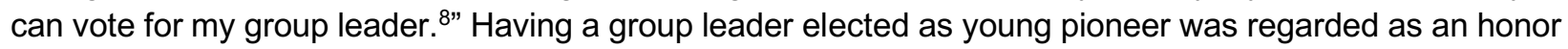
for the whole group.

Then there were parents' part of the campaign, which usually involves showing some kindness to the teacher. Once, I overheard one of my friend's mother telling my mom that she bought a bottle of a luxurious face lotion for the teacher, Ms. Liu. Those days leading to the election for "young pioneers" were my first exposure to the practice of politics.

A few days later, the election was held in classroom. First of all, the first graders raised hands to volunteer and nominate the candidate. Ms. Liu wrote all the names on the blackboard. Then, she went over the names again, and we would raise hands to show our vote. She counted the hands and wrote the number behind the names on the blackboard. The name with the highest number won the election.

Somehow, I took it for granted that considering my smartness and "good behaviors" in class and the fact that I was adorned by teachers and fellow students, I deserved the red scarf. I could hardly remember or comprehend who were selected by the students and who were finally selected for the ceremony. I just remember that I proudly joined the line of students waiting to be offered the red scarf on the day of the ceremony.

When the teacher counted all the students in the line, well, there were 11 of us rather than 10 . "One person is not supposed to be offered the red scarf today," The teacher asked. "Who was not on the name list?"

At once, another girl claimed that it was me who was not on the name list. I immediately claimed that another girl was the extra one. The argument disturbed the whole event and as a result, I was exiled from the "young pioneers" group for our disrespect of the rules of the event. (I did not know whether I was elected or not until today, but it did not matter at all when Ms. Liu dragged me out of the line.)

I did not realize how "young pioneers" would affect my life until later that day. In math class, after my teacher Ms. Huang asked a question, I raised my hand immediately. But she did not call my name. Instead, she said: "Today, I will let a young pioneer to answer my question." All the students who were not young pioneers dropped their heads. The other day, I was playing a game with a group of friends and I wanted to explain the rule to someone that just joined. The girl said to me coldly, "why would I listen to you? You are not even a young pioneer!"

In retrospect, the selection of young pioneers was based on a mixture of factors: willingness and the abilities to obey the authority, students' talent in academic subjects, popularity, family backgrounds, parents' influences, and even the teachers' impression of the students. However, in my experiences, the selection was normalized as honor and loyalty to the country and the communist party through a democratic process.

I guess I did not have much to complain as I, at least, were from middle class families. I was born after the implementation of "one child only" policy in China. Growing up, I keep hearing my relatives telling

${ }^{8}$ A 2007 documentary, "Please vote for me", produced by Don Edkins, following a third grade class in China may provide you details of a similar election. The documentary won the Sterling Feature Award at Silverdocs in 2007. 
me: "You are so lucky being a girl. Grandma already had three grandsons and no granddaughter yet. She was really looking forward to have a granddaughter, which was such a perfect timing for you. Otherwise..." Otherwise, I have heard people aborted or killed their born female babies in order to have a son in the family. I also remember sharing snacks with a close friend of mine who did not have any pocket money because her parents only gave her younger brother pocket money, not to girls.

I have personally witnessed numerous girls quit middle or high schools because their families did not want to support a girl's education. I have also known girls sending all the money they earned to parents immediately after they started working so that their parents could buy a house for their brothers to marry and to carry the name of the family. Whenever my relatives telling me this, I shivered in their voices.

Fortunately, I grew up in a protected environment as from early on -- my mom started talking to me that a girl can be as capable as any boys in any aspect. However, I could hear as girls would gather together and discuss: "The math teacher said that even if I tried really hard to excel in math now, after middle school, math track would not suit me as a girl." We talked about the unfair treatment we received and often, those discussions ended in resentful comments: "Being a girl is a sin." "If I had an after-life, I would make sure I was a boy." I saw those girls internalized the denigration of girls and women so helplessly.

When I think about childhood, more often, I think about the summer nights. When it was too hot in Wuhan, people would carry bamboo beds and slept on the side of the streets, chatting, singing, counting stars. Every night I was determined to stay up late for all the good stories my uncle had to tell, an episode of Monkey King for instance. Every night, I ended up being the first one falling asleep. I think about the afternoons that I was pretending to do math problems in the room while holding my breath, waiting for the cry of the vendors walking passed by: Sweet tofu soup for one yuan. I took the one yuan note my mom left me, ran downstairs and two minutes later, came back to the room with a bowl of the sweetest tofu soup in the world. I think about the 10 minutes recess I had in between the classes in elementary school. Within that ten minutes, I was able to ran downstairs with my friends, from the classroom on the fourth floor, play hide-and-seek, play chasing, play sands, and then ran back to the classroom when the class resumed. How I was able to do all that within 10 minutes is beyond my concept of time now as an adult.

\section{Memories of the past}

On the day that I was excluded from the "young pioneers", my mom consoled me with her stories. She was neither a "young pioneer", nor a "small-group-leader," although she always had the highest grades in her class.

At her time, the composition of family backgrounds was crucial and a clean background was needed to be elected for anything. Unfortunately, before 1948, my grandpa used to own a small factory and was a "petty capitalist," according to the State, for that matter. My mom could not be elected or selected for any position because of the past bad social status of her father. My auntie had even more sad stories to tell since she was an exceptionally talented volleyball player. Her application to the province's team were repeatedly rejected because of the composition of grandpa despite that the province's team "borrowed" her to play in every important game.

I was hardly consoled because I did not like my aunt in the first place. "Everyone had to face hardship in life," my mom used to say. Also, see, in 1993, no one cared about the composition of the family anymore, and that was a tremendous improvement compared to twenty years before. 
As a loyal young citizen, I didn't like the fact that my grandparents were "petty capitalists" either. After reading stories of the Red Army's fighting "capitalists" in textbook, I went home in tears and asked my mom, "Are my grandparents capitalists? If so, they are evil, and we should not visit them anymore." But, I wondered, "Why do they cook the best roast duck in the world?!" Retrospectively, I couldn't remember how I reconcile the dissonance between the official discourse and the personal experiences. The pressure to conform was so strong that any dissent was unimaginable.

The first time my dad told me he used to crave for rice when he was a kid, I told him, that kinds of reality could only exist in an evil capitalist society. My dad was so shocked by how modern Chinese history was taught in schools and started to tell me his childhood. He was 5 years old when The Great Famine ${ }^{9}$ swept China between 1958 and 1961. Many years later, I read one of Mo Yan's (A Chinese Nobel Literature Prize Laureate) novel, in which he vividly described how his friend and he ate coal during the famine, what the coal tasted like, smelled like, and how it gave him a sense of fullness during the desperate time. However, today, when I raised the fact that the history textbooks in China tend to be single-sided story and did not capture his experiences, my dad would say, "That's ok. It doesn't matter. As long as our life is much better off now. That's ok." In my analysis, it is hard to say if he internalized the conformity required in Confucianism culture or the totalitarian regime, or, honestly, he cherished his life after the "reform and open" policy and did not want to lose such peaceful and prosperous life.

My dad went to school during the era of Cultural Revolution ${ }^{10}$. He told me in his elementary school, there was no textbook or learning materials, the teacher would just teach whatever comes to her mind. He had one notebook. After he finished the whole book with a pencil, he would erase the whole notebook with an eraser and reuse the notebook. When he went to the middle school, he finally got textbooks. But the textbooks were so thin he would finish reading a whole semester's book within three days. Despite that, at the beginning of every chapter, there were two pages of "Chairman Mao says." For instance, "Chairman Mao says all the capitalist enemies are paper tigers. We should not fear them at all." And all the classes began by chanting "Chairman Mao says" for ten minutes, then a real lecture began.

Till today, whenever he wanted to encourage me to do something fearlessly, he would begin, "All the capitalist enemies are paper tigers......" When, not long time ago, I was doing my graduate school work in Western universities, the chant seemed really appropriate to me.

Well, back to his middle school. The other reason that the textbooks were so thin back then was that they were only in school for half a day at the time. The rest of the time, the whole school would work in a factory because "workers were the best teachers, not the books or the academy." Since they were so young, they would do simple and repetitive work like folding boxes, or washing cloth. Again, complaining would only make it worse because showing disrespect for factory workers, who were the best teachers for the academy, was a crime.

My father said one of his classmate entered the university by turning in a blank examine paper in English tests. Well, not all blank, but he wrote a Chinese poem on the English language examine paper: "English sounds like dog talk and French sounds like cat talk. Since our society is better than theirs, why do we have to learn their languages? Long live Chairman Mao!" The whole school was shocked by his

\footnotetext{
${ }^{9}$ https://en.wikipedia.org/wiki/Great Chinese Famine

${ }^{10}$ Cultural Revolution was a sociopolitical movement in China from 1966 to 1976 . Its stated goal was to preserve the "true" communist ideology in the country by purging remnants of capitalist and traditional elements from the Chinese society. However, the movement paralyzed China politically and negatively affected the country's economy. https://en.wikipedia.org/wiki/Cultural Revolution
} 
courage. A lot of foreign language teachers stopped teaching for fear that they would be caught teaching "capitalist languages".

The teaching about the Evil Capitalism affected my dad's life in every aspect. He had eight sisters and brothers. The family had to save the food for those who work in the field, as a child, he had always suffered from malnutrition. Corn buns were the only thing available to him. His neighbors who had only two children would have white wheat buns. When my dad told his teacher that he craved for white wheat buns, his teacher said, "White wheat buns are bad for your spirit - they spoil your stomach and make you weaker in facing the famine." White wheat buns were "capitalist food". I do not know what exactly shaped his personality: the famine or his teachers' talk. Nowadays, whenever I eat with my dad, I would eat all the dishes proportionally, avoiding showing him which food I like, otherwise, he would lecture: that food (the food I apparently liked, chicken wings, for instance), is bad for your spirit, it would make you weaker in facing the enemy.

Nevertheless, whenever my dad talked about his childhood, he always ended his stories by praising the current economic development in China. He grew up in a family that treated white wheat buns as luxury. By the time he entered college, food was no longer a problem. A few years after he got his college degree and started to work in an export company, he bought bikes, televisions, and telephones. He is very satisfied with what he got despite that he hated the current history school textbooks. In China, the economic development in recent decades had become so successful and loomed large in media, that all the other problems seem tolerable.

\section{Conclusion}

This essay is a memoir about my childhood in post-socialist China in 1990s. On one hand, my experience was marked by the formal discourse of a socialist regime: the election to join "young pioneers", the curriculum about revolutionary past, and the dancing competitions devoted to the party. On the other hand, after the "reform and open" policy in China, opportunities for the upward social mobility emerged. While my parents, who were traumatized by the experiences of poverty and famine enjoyed such opportunities, they pushed me to pursue such competitive opportunities against all the odds.

In my experiences, sometimes, the two discourses intersect, other times, I experienced conflicts of the two discourses. While my parents were dissatisfied with the official discourse of socialist regime, the pursuit for a well-off life was normalized as the benefit of "New China". Therefore, they support the current socialist regime whole-heartedly. For my generation, growing up with endless course work, Disney movies and Nintendo games, the suffering past is almost forgotten. However, if you look really closely, through the red collar that children wore, the songs that were taught in schools, the elections for class monitor, you could see the past like a ghost, peeking out behind the curtain. 


\section{(cc) EY}

New articles in this journal are licensed under a Creative Commons Attribution 4.0 United States License.

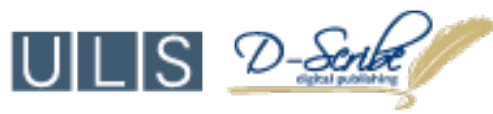

This journal is published by the University Library System, University of Pittsburgh as part of its D-Scribe Digital Publishing Program and is cosponsored by the University of Pittsburgh Press. 